\title{
Life history, distribution and abundance of the giant earthworm Rhinodrilus alatus RIGHI 1971: conservation and management implications
}

\author{
Drumond, MA. ${ }^{a}$, Guimarães, $A Q .^{b,{ }^{*}}$, El Bizri, HR. ${ }^{a}$, Giovanetti, LC. ${ }^{b}$, \\ Sepúlveda, DG. ${ }^{b}$ and Martins, $R P^{c}{ }^{c}$ \\ ${ }^{a}$ Departamento de Biologia Geral, Instituto de Ciências Biológicas, Universidade Federal de Minas Gerais, Bloco I3, 175. \\ Avenida Antônio Carlos 6627, Pampulha. CEP 31270-901 Belo Horizonte, MG, Brazil \\ ${ }^{b}$ Instituto Sustentar, Av. Hum 2863, Casa Branca, CEP 35460-000 Brumadinho, MG, Brazil \\ ${ }^{c}$ Departamento de Biologia, Centro de Ciências, Universidade Federal do Ceará, Av. da Universidade 2853, \\ CEP 60020-18 Fortaleza, CE, Brazil \\ "e-mail: sustentar@sustentar.org.br
}

Received June 13, 2012 - Accepted October 3, 2012 - Distributed November 29, 2013

(With 4 figures)

\begin{abstract}
Rhinodrilus alatus is an endemic giant earthworm of the Brazilian Cerrado hotspot used as live bait for about 80 years. The goal of this study was to gather ecological data about this species, which will support the establishment of management strategies. The life history, distribution and abundance of $R$. alatus were investigated in Cerrado, pastures and $E u$ calyptus plantation areas following the harvesting activities of the local extractors of this species. We found that this earthworm is abundant in all of the sampled areas, showing its resilience to land-use conversion. The Capture Per Unit Effort was $4.4 \pm 5$ individuals per 100 metres of transect and 5.6 3 individuals per hour. The earthworm's annual cycle is markedly seasonal, with an aestivation period throughout the driest and coldest season of the year. Significant differences in the length and diameter of the body and in the diameter and depth of the aestivation chambers were found between the juveniles and adults. The distribution range of the species was expanded from two to 17 counties. The life history, abundance, distribution and resilience of $R$. alatus to certain perturbations are key elements to be considered in conservation and management strategies for this species.
\end{abstract}

Keywords: adaptive strategies, Cerrado, life history, Oligochaeta, conservation biology.

\section{História de vida, distribuição e abundância do minhocuçu Rhinodrilus alatus RIGHI 1971: implicações para sua conservação e manejo}

\section{Resumo}

Rhinodrilus alatus é um minhocuçu endêmico do hotspot Cerrado, utilizado como isca viva por cerca de 80 anos. O objetivo deste estudo foi obter informações ecológicas sobre essa espécie, as quais servirão para o estabelecimento de estratégias para seu manejo. A história de vida, a distribuição e a abundância de $R$. alatus foram investigados em áreas de Cerrado, pastagens e plantações de Eucalyptus, acompanhando sua extração pela comunidade local. Rhinodrilus alatus foi abundante em todas as áreas amostradas, mostrando-se resiliente à conversão do Cerrado em outros usos. A Captura por Unidade de Esforço foi de $4.4 \pm 5$ indivíduos por 100 metros de transecto e $5.6 \pm 3$ indivíduos por hora. $\mathrm{O}$ ciclo anual do minhocuçu é marcadamente sazonal, apresentando estivação no período mais frio e seco do ano. Jovens e adultos diferiram significativamente no comprimento e diâmetro do corpo e no diâmetro e profundidade da câmara de estivação. A distribuição da espécie foi expandida de dois para 17 municípios. A história de vida, a abundância, a distribuição e resiliência de $R$. alatus por certos distúrbios são elementos chave a serem considerados nas estratégias de conservação e manejo dessa espécie.

Palavras-chave: estratégias adaptativas, Cerrado, história de vida, Oligochaeta, biologia da conservação.

\section{Introduction}

Approximately 960 species of terrestrial Oligochaeta, $93 \%$ of which are native species, are known in Latin America (Fragoso and Brown, 2007). In all, 305 species
(85\% native and 15\% exotic) are found in Brazil. However, given the current research gaps, ecosystem diversity, climatic conditions and size of the country, the total number of species is estimated at more than 1,400 
(Brown and James, 2007). Despite the recognised importance of earthworms for the maintenance of ecological processes and ecosystem services, the small number of specialists working with this group, primarily taxonomists, is a factor that contributes to the lack of knowledge about the biology and ecology of earthworms (Brown and James, 2006; Brown and James, 2007).

Giant earthworms inhabit all continents. In Brazil, 51 of the 53 giant species belong to the Glossoscolecidae family, primarily in the genera Rhinodrilus and Glossoscolex (Brown and James, 2007), and only five of the 53 species reach more than one metre in length (James and Brown, 2006). Although giant earthworms can be found in all of the biomes of Brazil, most of the largest species are found only in areas of native vegetation in the Atlantic Forest biome (James and Brown, 2006).

The Cerrado biome encompasses $20 \%$ of the territory of Brazil (Mittermeier et al., 2004) and has the richest flora among the world's savannas and high levels of endemism (Klink and Machado, 2005). The endemic species Rhinodrilus alatus RIGHI 1971 is one of the 54 species of earthworms known to inhabit the Cerrado (Brown and James, 2007). The species has been used as bait by sport fishermen since the 1930s (Drumond et al., 2008). However, despite the almost secular human use of the species and its established taxonomic status (the species was described 40 years ago), there is little information about its biology and ecology (e.g. Righi, 1971; Hofling, 1980; Righi and De Maria, 1998; Brown and James, 2007; Drumond et al., 2008).

Considering its long history of extraction from the habitat to supply the demands of fishermen, R. alatus appears to be resilient to the present high levels of exploitation and habitat losses. Although thousands of $R$. alatus individuals are extracted every year in the region, the supply of giant earthworms to be used as bait has always met the demand (Drumond, 2008; Drumond et al., 2008).

This study aimed to provide information about the life history, abundance and distribution of $R$. alatus and also to assess how these data could assist the conservation and management of the species.

\section{Material and Methods}

\subsection{Study area}

This study was conducted in 17 municipalities of the central region of the Cerrado hotspot in Minas Gerais state (N 17.600141, S 19.613570; E 43.736822, W 45.361379) (see Figure 1, Table 1). Different vegetation types occur in the study area, including trees and shrub savannas (Cerrado strictu sensu) and occasional patches of a closed-canopy forest called Cerradão. Native vegetation covers $46 \%$ of the studied region. Exotic Eucalyptus spp. monocultures represent $9 \%$ of the region's cover, and other plantations, such as Brachiaria spp. pastures, cover the remainder (Scolforo et al., 2006).

Although the Cerrado receives abundant rainfall (average of $1,500 \mathrm{~mm} /$ year), it is concentrated in a period of

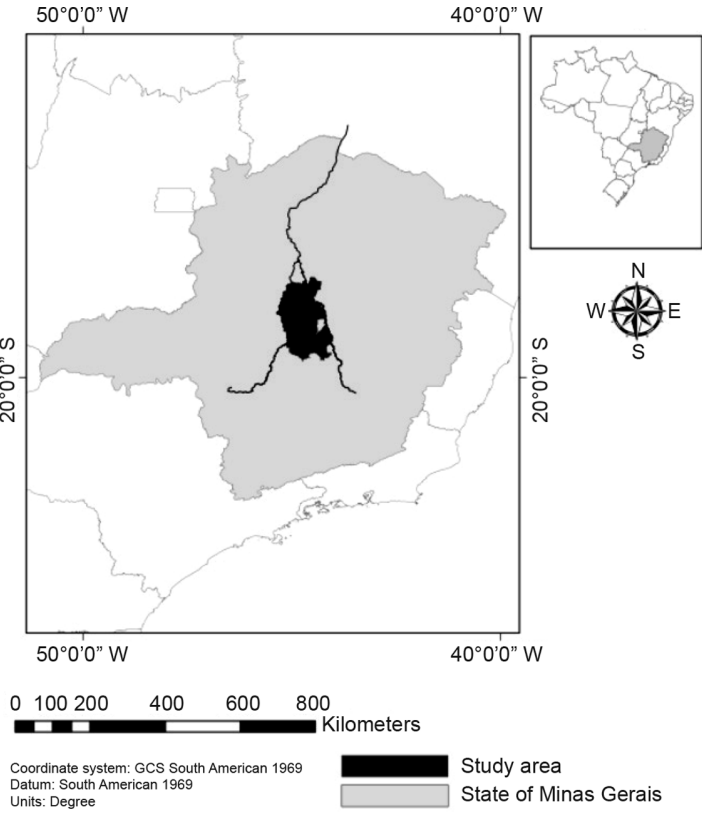

Figure 1 - Study area located in the Cerrado biome, in the central region of the state of Minas Gerais, Brazil (N 17.600141, S 19.613570; W 45.361379, E 43.736822).

six to seven months between October and March, primarily during the spring and summer. The autumn and winter are characterised by a pronounced dry season (Klink and Machado, 2005).

\subsection{Sampling and biometry}

A total of 839 earthworms were extracted directly from the soil with the aid of a short-handled grub hoe. Fifty five earthworms were extracted during the rainy season and 784 during the dry season, from April 2006 to July 2011.

Adults and juveniles were collected from Cerrado $(\mathrm{n}=376)$, Cerradão $(\mathrm{n}=210)$, Brachiaria spp. pastures $(\mathrm{n}=192)$ and Eucalyptus spp. plantations $(\mathrm{n}=61)$. The body length and diameter were measured with a tape and a pachymetre, respectively, immediately after the removal of the earthworms, while its body was relaxed (not contracted or distended). The diameters of the aestivation chambers and subterranean galleries were also measured when present. Four cocoons and their chambers were measured with a pachymetre and a tape.

\subsection{Abundance}

The abundance of the giant earthworms was estimated using the Capture Per Unit Effort (CPUE = number of individuals/person/hr or number of individuals/person/metres) calculated from the data obtained in the field by following the harvesting activities of the local extractors during the dry seasons of 2006, 2007, 2010 and 2011. We followed 16 different extractors in eight counties along 27 transects for a total of $21.49 \mathrm{~km}$ and 96 working hours. All of the transects were plotted and 
Table 1 - Number of individuals of Rhinodrilus alatus collected and number of soil samples by municipality and vegetation type of the state of Minas Gerais.

\begin{tabular}{|c|c|c|c|c|}
\hline Municipality & Vegetation type & Number of individuals & Number of localities & Number of soil samples \\
\hline Araçaí & Cerrado & 7 & 2 & - \\
\hline Baldim & Cerrado & 2 & 1 & - \\
\hline Caetanópolis & Brachiaria spp. & 65 & 2 & - \\
\hline Caetanópolis & Cerrado & 10 & 1 & - \\
\hline Cordisburgo & Eucalyptus spp. & 1 & 1 & - \\
\hline Cordisburgo & Brachiaria spp. & 23 & 2 & - \\
\hline Cordisburgo & Cerradão & 27 & 1 & 3 \\
\hline Cordisburgo & Cerrado & 14 & 1 & - \\
\hline Corinto & Cerradão & 33 & 1 & - \\
\hline Corinto & Cerrado & 5 & 1 & - \\
\hline Corinto & Cerrado & 3 & 1 & - \\
\hline Curvelo & Cerrado & 96 & 8 & 3 \\
\hline Curvelo & Cerradão & 26 & 2 & 15 \\
\hline Curvelo & Cerrado & 6 & 1 & - \\
\hline Felixlândia & Cerrado & 4 & 1 & - \\
\hline Felixlândia & Cerradão & 1 & 1 & 3 \\
\hline Inhaúma & Cerrado & 6 & 1 & - \\
\hline Lassance & Cerrado & 1 & 1 & - \\
\hline Maravilhas & Cerradão & 19 & 1 & 6 \\
\hline Morro da Garça & Cerradão & 31 & 1 & 9 \\
\hline Papagaios & Cerrado & 31 & 2 & 3 \\
\hline Paraopeba & Cerradão & 62 & 3 & 3 \\
\hline Paraopeba & Eucalyptus spp. & 46 & 1 & 6 \\
\hline Paraopeba & Cerrado & 151 & 3 & 3 \\
\hline Paraopeba & Brachiaria spp. & 104 & 2 & 6 \\
\hline Pompéu & Cerrado & 28 & 3 & 6 \\
\hline Prudente de Moraes & Cerradão & 4 & 1 & - \\
\hline Sete Lagoas & Cerrado & 6 & 1 & - \\
\hline Três Marias & Eucalyptus spp. & 14 & 1 & 12 \\
\hline Três Marias & Cerradão & 7 & 1 & - \\
\hline Três Marias & Cerrado & 6 & 1 & - \\
\hline Total & 839 & 51 & 78 & \\
\hline
\end{tabular}

georeferenced. The allocation of transects was defined by the extractors based on the observation of castings and galleries. These observations indicated the presence of earthworms in aestivation chambers. The number of individuals extracted, the distance traveled and the time spent on each transect by the extractor were recorded to obtain the CPUE. In addition, 12 plots, each $100 \mathrm{~m}^{2}$, were defined in areas of Cerrado ( $\mathrm{n}=8$ plots $)$ and in surrounding pastures ( $\mathrm{n}=4$ plots) in Paraopeba. In these plots, an effort was made to collect all of the individuals present in the area.

\subsection{Soil analyses}

Soil analyses were performed in order to relate textural and chemical characteristics with the sites of occurrence and the life history of $R$. alatus. Sites without $R$. alatus were not sampled once all the following harvesting activities had success in capture by the extractors. In 2006 we collected 78 soil samples next to the aestivation chambers of 26 earthworms (three different samples per individual) from 17 locations in nine of the 17 study municipalities (see Table 1). The samples were analysed for 
Table 2 - Body length, body diameter, chamber diameter and chamber depth of adult and juvenile Rhinodrilus alatus.

\begin{tabular}{lcccccccccc}
\hline Parametre & \multicolumn{2}{c}{ Mean } & \multicolumn{2}{c}{$\begin{array}{c}\text { Number of } \\
\text { individuals }\end{array}$} & \multicolumn{2}{c}{$\begin{array}{c}\text { Standard } \\
\text { deviation }\end{array}$} & \multicolumn{2}{c}{ Minimum } & \multicolumn{2}{c}{ Maximum } \\
\hline Sexual maturity $^{\mathrm{a}}$ & $\mathrm{J}$ & $\mathrm{A}$ & $\mathrm{J}$ & $\mathrm{A}$ & $\mathrm{J}$ & $\mathrm{A}$ & $\mathrm{J}$ & $\mathrm{A}$ & $\mathrm{J}$ & $\mathrm{A}$ \\
Body length $(\mathrm{cm})^{* *}$ & 43.2 & 69.4 & 282 & 431 & \pm 15.1 & \pm 18.7 & 4.9 & 24.0 & 87 & 129 \\
Body diameter $(\mathrm{cm})^{*}$ & 0.77 & 1.29 & 66 & 115 & \pm 0.19 & \pm 0.21 & 0.5 & 0.90 & 1.20 & 1.90 \\
Chamber diameter $(\mathrm{cm})^{* * *}$ & 4.20 & 5.91 & 249 & 374 & \pm 0.95 & \pm 0.97 & 2.0 & 3.0 & 7.0 & 9.0 \\
Chamber depth $(\mathrm{cm})^{*}$ & 24.9 & 26.6 & 257 & 374 & \pm 6.2 & \pm 7.0 & 11.5 & 2.0 & 53 & 50.0 \\
\hline
\end{tabular}

${ }^{a}$ Sexual maturity level: $\mathrm{J}=$ Juvenile; $\mathrm{A}=$ Adult. ${ }^{*} \mathrm{p}<0.01 .{ }^{* *} \mathrm{p}<0.001 .{ }^{* * *} \mathrm{p}<0.0001$.

$\mathrm{pH}$, phosphorus, potassium, calcium, magnesium, exchangeable aluminum and organic matter content. The texture class of the soil was determined by its clay, silt and sand composition according to Curi et al. (2007). The soil analyses were performed at EMBRAPA SOJA (Empresa Brasileira de Pesquisa Agropecuária) soil laboratory according to the method described in EMBRAPA (1997).

\subsection{Statistical analyses}

Logistic regression and a t-test were used to test the relationship between these variables and sexual maturity. A t-test with separate variances was used in those cases in which the assumptions of the standard t-test had not been satisfied. A Pearson chi-squared test was used to compare the sampling of adults and juveniles in the different vegetation types. Statistica version 8.0 (StatSoft Inc., Tulsa, USA) was used for the statistical analyses, and $\mathrm{p}<0.05$ was considered significant.

\section{Results}

The giant earthworms are found to be $58.4 \pm 21.1 \mathrm{~cm}$ long, but we found an individual approximately $130 \mathrm{~cm}$ long; only 10 juveniles shorter than $20 \mathrm{~cm}$ were sampled.
The earthworms are $1.1 \pm 0.31 \mathrm{~cm}$ in diameter, the largest approximately $2 \mathrm{~cm}$ in diameter (see Table 2). Individuals measuring between 21 and $80 \mathrm{~cm}$ in length were the most common (85\%), although some individuals reach more than one metre (see Figure 2). The mean body length of adults was $69.4 \mathrm{~cm} \pm 18.7$ and the mean body length of juveniles was $43.3 \pm 15.1$ (see Table 3 ). The

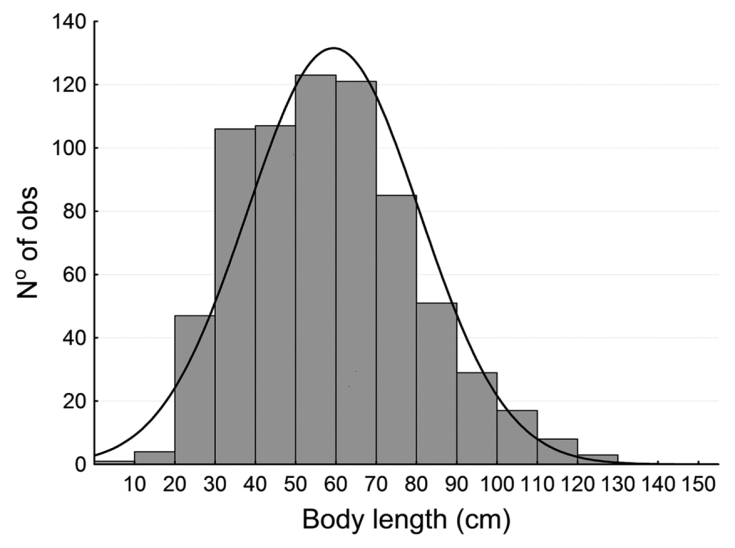

Figure 2 - Population structure of the giant earthworm Rhinodrilus alatus relative to the body length $(\mathrm{n}=808)$.

Table 3 - Abundance and frequency of juveniles and adults of Rhinodrilus alatus extracted in different vegetation types.

\begin{tabular}{|c|c|c|c|c|c|c|}
\hline Vegetation types & $\begin{array}{c}\text { Sexual } \\
\text { maturity }\end{array}$ & $\begin{array}{l}\text { Number of } \\
\text { individuals }\end{array}$ & $\begin{array}{l}\text { Frequency (per } \\
\text { environment) }\end{array}$ & Mean & $\begin{array}{l}\text { Standard } \\
\text { deviation }\end{array}$ & Total \\
\hline \multirow[t]{2}{*}{ Cerrado } & Juveniles & 138 & $44.09 \%$ & 3.2 & \pm 3.3 & 313 \\
\hline & Adults & 175 & $55.91 \%$ & 3.8 & \pm 3.1 & \\
\hline \multirow[t]{2}{*}{ Cerradão } & Juveniles & 66 & $36.87 \%$ & 3.6 & \pm 6.3 & 179 \\
\hline & Adults & 113 & $63.13 \%$ & 6.3 & \pm 4.9 & \\
\hline \multirow[t]{2}{*}{ Eucalyptus spp. } & Juveniles & 16 & $31.37 \%$ & 2.3 & \pm 2.0 & 51 \\
\hline & Adults & 35 & $68.63 \%$ & 5.0 & \pm 4.4 & \\
\hline \multirow[t]{2}{*}{ Brachiaria spp. } & Juveniles & 61 & $36.53 \%$ & 3.1 & \pm 4.2 & 167 \\
\hline & Adults & 106 & $63.47 \%$ & 5.8 & \pm 5.0 & \\
\hline \multirow[t]{2}{*}{ Total } & Juveniles & 281 & $39.58 \%$ & 3.2 & \pm 4.2 & 710 \\
\hline & Adults & 429 & $60.42 \%$ & 4.9 & \pm 4.2 & \\
\hline
\end{tabular}


specimens greater than one metre long have a $100 \%$ probability of being adults $\left(\mathrm{chi}^{2}=324.36\right.$, df $=1$, $\mathrm{p}<0.0001, \mathrm{n}=713$ ) (as shown in Figure 3). The lengths of the juveniles and the adults differ significantly (t-value $=20.59, \mathrm{df}=676.9, \mathrm{p}$-value $<0.001$ ), as do the diameters (t-value $=16.84, \mathrm{df}=151.1, \mathrm{p}$-value $<0.01$ ) (see Table 2).

Therefore, the body size and diameter are parameters that reflect the level of sexual maturity $\left(\mathrm{chi}^{2}=161.28\right.$, $\mathrm{p}<0.0001, \mathrm{n}=181$ ) according to the following equation (see Figure 3):

$$
F=\frac{2.72^{(-12.761+0.051108 x+10.1614 y)}}{1+2.72^{(-12.761+0.051108 x+10.1614 y)}}
$$

where $F=$ probability of finding adults, $x=$ body length $(\mathrm{cm})$ and $y=$ diameter $(\mathrm{cm})$.

\subsection{The annual cycle}

The annual cycle of $R$. alatus is markedly seasonal. The reproductive and foraging phases occur during the rainiest and hottest seasons (spring and summer). During the summer months of January and February, $R$. alatus builds two subterranean galleries and an aestivation chamber. One of these galleries can be obstructed by the last feces produced before the aestivation phase and the second gallery is used by the earthworm to exit the chamber and reach the soil surface (for more details see Drumond et al., 2008). The subterranean galleries are 1.2 $\pm 0.2 \mathrm{~cm}$ in diameter (maximum $=2.0$ and minimum $=0.4 \mathrm{~cm}, \mathrm{n}=702$ ).

Each worm remains coiled inside its aestivation chamber throughout the driest and coldest seasons (autumn and winter). The aestivation chambers are $5.15 \pm 1.3 \mathrm{~cm}$ in diameter and are located $25.8 \pm 6.8 \mathrm{~cm}$ below the soil surface, but the depth ranges from $2 \mathrm{~cm}$ to $53 \mathrm{~cm}(\mathrm{n}=737)$ (see Figure 4).

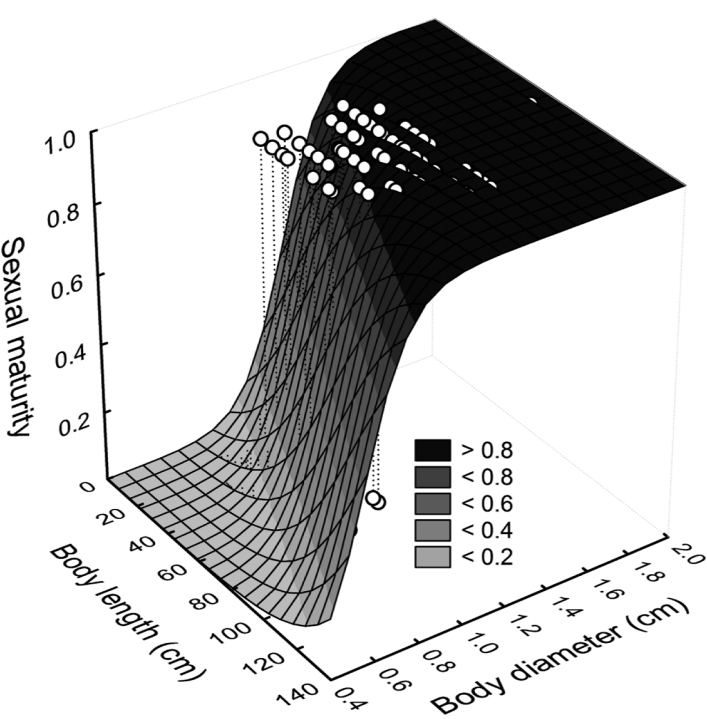

Figure 3 - Sexual maturity curve for the giant earthworm Rhinodrilus alatus as a function of the body length and diameter $(\mathrm{n}=181)$.

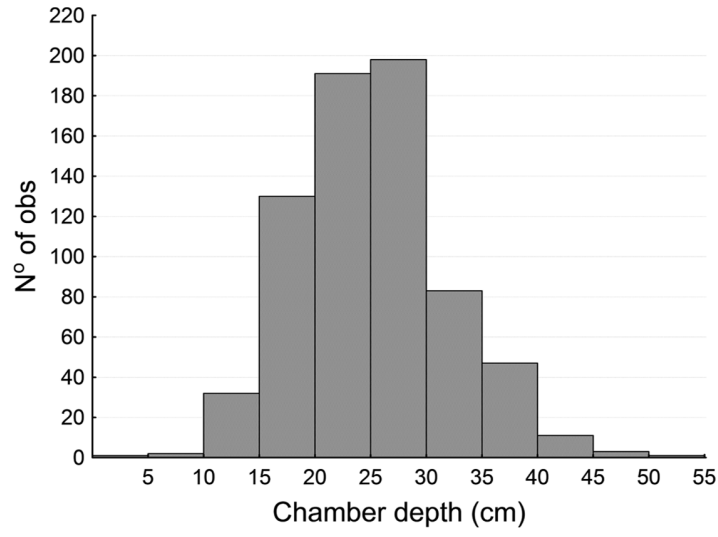

Figure 4 - Depth (in $\mathrm{cm}$ ) of the aestivation chambers of the giant earthworm Rhinodrilus alatus $(\mathrm{n}=737)$.

If the subterranean gallery is $1.8 \mathrm{~cm}$ or wider in diameter, the probability of finding an adult inside the aestivation chamber is $100 \%(\mathrm{chi} 2=266.37, \mathrm{df}=1, \mathrm{p}<0.0001$, $\mathrm{n}=605$ ).

There is a slight but significant difference (t-value $=$ $21.61, \mathrm{df}=621, \mathrm{p}<0.0001)$ between the depth values of chambers with adult worms and chambers with juveniles (see Figure 4 and Table 1). Similarly, there is a small but significant difference $(\mathrm{t}$-value $=3.17, \mathrm{df}=593, \mathrm{p}<0.01$ ) between the diameter values of the aestivation chambers for these groups (see Table 2).

The chamber has a smooth internal surface; during aestivation, $R$. alatus produces a protein silk cover around itself and the aestivation chamber that retains moisture. At the end of the aestivation period, mature individuals prepare for reproduction and the glands associated with the clitellum increase in volume and are projected laterally. According to the common knowledge coming from the extractors, these sexual characters regress when reproductive period ends.

At the beginning of the rainy season, the giant earthworms leave their aestivation chambers to feed and reproduce. The trail lengths left by the giant earthworms indicate that they can cover long distances on the ground surface, although this characteristic was not measured in the present study (for more details see Drumond et al., 2008). Mating was only observed in September $(n=16)$. During the reproductive period, the ventral surface of the bodies becomes rougher due to the texture of the bristles. The clitellum of a fertilised earthworm excretes the mucus used to produce the cocoons. The cocoon is difficult to locate because it is isolated inside a circular subterranean chamber, which measures $4.3 \pm 5.1 \mathrm{~cm}$ in diameter $(\mathrm{n}=3)$. We observed only two individuals per cocoon $(\mathrm{n}=4$ cocoons). The new young measure $13.1 \pm 1.1 \mathrm{~cm}$ in length $(n=6)$.

After mating, R. alatus builds a U-shaped subterranean gallery. The earthworms forage on one side of this gallery and leave tower-like casts on the opposite side of the gallery on the soil surface. From October to March, especially in the first months of this period, the giant 
earthworms are prone to autotomy, losing their caudal portions when handled; scarring is instantaneous.

\subsection{Characteristics of the occurrence and distribution areas of Rhinodrilus alatus}

Rhinodrilus alatus occurs in all of the different vegetation physiognomies of the Cerrado biome and in pastures and Eucalyptus fields in at least 17 districts of the São Francisco River Basin, covering an area of $20,296.91 \mathrm{~km}^{2} \quad$ (N 17.600141, S 19.613570; E 43.736822, W 45.361379). The species was recorded in all areas where we followed the local extractors' harvesting activities. We did not research in areas converted to agriculture because the extractors do not visit them, since they recognise $R$. alatus could not occur in these areas.

The soils next to the $R$. alatus chambers are primarily clayey and silty clays, very acidic ( $\mathrm{pH} 4.70 \pm 0.19)$ and distrofic $(\mathrm{V} \%=11.82 \pm 8.35)$ according to EMBRAPA (2006) and Tan (2003) (seeTable 4).

\subsection{Abundance}

The extractors collected $4.4 \pm 5$ earthworms in 100 metres of transect and $5.6 \pm 3$ individuals per hour. The number of adults collected by the extractors was greater than the number of juveniles, regardless of whether the extraction occurred in the Cerrado, Cerradão, Brachiaria spp. or Eucalyptus spp. $\left(\mathrm{chi}^{2}=5.30\right.$, $\mathrm{df}=3, \mathrm{p}>0.05)$ (see Table 3$)$.

In the 12 study plots $\left(1,200 \mathrm{~m}^{2}\right), 198$ individuals were captured, with a mean of $16.5 \pm 13.2$ individuals/plot $100 \mathrm{~m}^{2}($ minimum $=2$, maximum $=44)($ see Table 5$)$. The plots located in the Cerrado had 13.4 \pm 14.6 individuals $/ 100 \mathrm{~m}^{2}$ (minimum $=2$, maximum $=44, \mathrm{n}=8$ ), whereas the pastures contained $22.8 \pm 7.5$ individuals $/ 100 \mathrm{~m}^{2}$ (minimum $=18$, maximum $\left.=44, \mathrm{n}=4\right)$. The number of individuals in the Cerrado plots does not differ from the number of individuals collected in the pastures plots $(\mathrm{t}=1.19, \mathrm{df}=10, \mathrm{p}>0.05)$.

\section{Discussion}

\subsection{Life history}

Soil moisture and temperature appear to be important factors in the aestivation process of $R$. alatus, as in most species of terrestrial Oligochaeta (Jiménez et al., 2000), although different species have different adaptive responses to environmental conditions (Lee, 1985; Edwards and Bolen, 1996; Diaz Cosín et al., 2006). For example, all of the species in a Colombian savanna remain inactive during the dry season, as is the case for $R$. alatus; however, certain species of the genera Andiodrilus and Andiorrhinus remain inactive at depths of almost $60 \mathrm{~cm}$ but do not build aestivation chambers and sustain high mortality (Jiménez et al., 2000). In contrast, the Colombian earthworm Glossodrilus n. sp. has a similar strategy to that of R. alatus, burrowing to depths of approximately $50 \mathrm{~cm}$ and building an aestivation chamber covered with mucus secreted by its tegument (Jiménez et al., 2000; Jiménez et al., 2007). The strategy of the giant Colombian earthworm Martiodrilus carimaguensis is also similar to that of $R$. alatus. M. carimaguensis builds a chamber at a depth of $60-110 \mathrm{~cm}$ where it remains during the dry season (Jiménez et al., 1998). This species also empties its gut contents and seals the chamber's entrances with feces to avoid moisture loss and maintain a moist environment that is vital to support a minimum res-

Table 4 - Mean, minimum and maximum values and standard deviation of chemical and textural characteristics of 78 soil samples collected next to aestivation chambers of Rhinodrilus alatus in nine municipalities of central region of Minas Gerais State.

\begin{tabular}{lcccc}
\hline $\begin{array}{l}\text { Soil chemical and } \\
\text { textural characteristics }\end{array}$ & Mean & Standard deviation & Minimum & Maximum \\
\hline $\mathrm{pH} \mathrm{H} 2 \mathrm{O}$ & 4.70 & 0.19 & 4.30 & 5.22 \\
$\mathrm{M} . \mathrm{O} \mathrm{g} / \mathrm{dm}^{3}$ & 24.48 & 8.70 & 7.84 & 45.41 \\
$\mathrm{P} \mathrm{mg} / \mathrm{dm}^{3}$ & 0.84 & 0.97 & 0.26 & 6.92 \\
$\mathrm{~K} \mathrm{cmolc} / \mathrm{dm}^{3}$ & 0.20 & 0.16 & 0.04 & 1.00 \\
$\mathrm{Ca} \mathrm{cmolc} / \mathrm{dm}^{3}$ & 0.39 & 0.38 & 0.08 & 1.89 \\
$\mathrm{Mg} \mathrm{cmolc} / \mathrm{dm}^{3}$ & 0.36 & 0.37 & 0.02 & 1.91 \\
$\mathrm{H}+\mathrm{Al} \mathrm{cmolc} / \mathrm{dm}^{3}$ & 6.96 & 1.66 & 4.08 & 12.42 \\
$\mathrm{~S} . \mathrm{B} . \mathrm{cmolc} / \mathrm{dm}^{3}$ & 0.95 & 0.80 & 0.19 & 4.39 \\
$\mathrm{CTC} \mathrm{cmolc} / \mathrm{dm}^{3}$ & 7.71 & 1.85 & 4.20 & 12.84 \\
$\mathrm{~V} \%$ & 11.82 & 8.35 & 2.23 & 41.43 \\
Clay \% & 64.63 & 13.74 & 18.51 & 78.96 \\
Silt \% & 25.68 & 13.64 & 72.81 & 6.95 \\
Sand \% & 9.69 & 4.46 & 2.74 & 23.56 \\
\hline
\end{tabular}


Table 5 - Number of individuals of Rhinodrilus alatus extracted in 12 sites of $100 \mathrm{~m}^{2}$ in areas of Cerrado and Brachiaria spp.

\begin{tabular}{lccccc}
\hline Municipalitie & Sampling plot & Vegetation type & \multicolumn{2}{c}{ Location (UTM) } & Number of individuals \\
\hline Curvelo & 1 & Cerrado & 534740 & 7888575 & 3 \\
& 2 & Cerrado & 534716 & 7888646 & 4 \\
& 3 & Cerrado & 534588 & 7888569 & 2 \\
& 4 & Cerrado & 534334 & 7885327 & 10 \\
\hline Paraopeba & 5 & Cerrado & 534208 & 7885230 & 3 \\
& 6 & Cerrado & 562410 & 7869469 & 44 \\
& 7 & Cerrado & 562640 & 7869620 & 25 \\
& 8 & Cerrado & 562307 & 7870031 & 19 \\
& 9 & Brachiaria spp. & 553580 & 7878635 & 18 \\
& 10 & Brachiaria spp. & 553222 & 7878579 & 34 \\
\hline
\end{tabular}

piration rate. A Mediterranean species, Hormogaster elisae, endemic to the Iberian Peninsula and found in a habitat where there is a strong summer drought, moves vertically and builds aestivation chambers at a depth of $50 \mathrm{~cm}$ in the soil (Valle et al., 1997; Valle et al., 1999; Días Cosín et al., 2006).

In Brazil, the activity of Chibui bari is restricted to six months a year, times when the soil moisture is above $20 \%$; for the rest of the year, this species remains in aestivation at a depth of approximately one metre (Guerra, 1985). Andiorrhinus samuelensis follows the recession of the groundwater during the dry season, reaching depths of more than nine metres, but it does not aestivate. Rather, it enters a lethargic state (Buck and Abe, 1990). Both of the above species are found in the Amazon biome. Glossoscolex paulistus, found in Cerrado habitats of São Paulo state, also builds an aestivation chamber of $50 \mathrm{~cm}$ depth (Abe and Buck, 1985).

Reports from the local community inhabiting the study area indicate additional characteristics not observed in this study but previously described for other species of giant earthworms. For example, the end of aestivation could be related to the chambers' depth, with earthworms in deeper chambers beginning their reproductive phase later than those in shallower chambers. This characteristic could be linked to an increase in the soil moisture because water reaches the deeper areas of the ground only if the rain is relatively constant. This behaviour could increase the survival of earthworms that build deeper chambers in areas where the soil moisture decreases drastically after a short rainy period.

According to Rodriguez et al. (2007), earthworms can also migrate to deeper soil layers in the Caribbean. Thus, these animals could be regarded as good indicator organisms for the evaluation of the effects of climate changes. For instance, with an increase in air and soil temperature it can be expected the aestivation chambers will be constructed at greater depths. Beyond that, the mortality rate of earthworms inactive in shallower chambers should be higher than those in deeper chambers. The existence of a historical series with this information can be useful for evaluating giant earthworms as indicators of climate changes. However, the effects of these changes on the majority of species are still unknown.

Brown and James (2007) discuss the difficulties associated with the captive breeding of giant earthworms. These difficulties include the low fecundity of adults, the late occurrence of sexual maturity and the long periods of incubation required for the cocoons. In addition, giant earthworms do not adapt well to conditions outside of their natural habitat. In a non-natural habitat, giant earthworms can survive but cannot reproduce. As is the case for other giant earthworms, the breeding of $R$. alatus in captivity has not been successful. We suggest that this difficulty is primarily due to the requirement of the species for large home ranges during the reproductive period.

Epigeic earthworms are exposed to continuous predation during all of their developmental stages, whereas under natural conditions, endogeic or anecic earthworms, which build galleries and subterranean chambers and estivate during part of their life cycle, can exhibit lower predation rates for both adult and juvenile individuals (Brown and James, 2007). It is probable that the construction of subterranean galleries by $R$. alatus is associated with strategies to cope with hydric stress. These galleries can also reduce the rates of predation on adults and juveniles.

Autotomy has been observed in other species of Oligochaeta (James and Brown, 2006). In Andiorrhinus caudatus, this phenomenon has been associated with anoxic conditions, as the species inhabits saturated soil and can survive 24 hours under water (Ayres and Guerra, 1981). Martin and Johansen (1992) observed autotomy for Glossoscolex giganteus under laboratory manipulations; as these authors observed that $G$. giganteus never 
eliminates its entire intestinal contents, they proposed that autotomy could be a mechanism to protect against the accumulation of large particles in the intestine (Martin and Johansen, 1992). We believe that autotomy for $R$. alatus is an anti-predator strategy to allow the survival of the individual and its progeny because, by leaving body parts behind for the predator, the individual can escape, regenerate and complete its reproductive cycle.

These biological characteristics can contribute to future management strategies. However, a management policy based on the depth of the chamber would not be an effective way to restrict the capture of giant earthworms to the adult stage because the differences in the chamber depths at different stages of maturity are small. Furthermore, despite the small difference in depth, the chambers of juveniles are slightly more superficial, thus theoretically increasing the probability that young will be more easily extracted. To prevent the extraction of juveniles, the extractors should capture earthworms only if the subterranean gallery is $1.8 \mathrm{~cm}$ or wider in diameter; although this approach is possible, we believe that it would be difficult in practice.

Although the relation between the species' biometric dimensions and sexual maturity is highly important, its application in management is restrict. For instance, the minimum body size, a parameter frequently used in conservation management programs, is inappropriate to manage $R$. alatus since an individual that has been extracted cannot survive outside its aestivation chamber if released back into the soil and exposed to conditions of lower moisture and higher temperature.

The earthworms are very fragile during their reproductive and foraging periods. They are prone to autotomy, die easily and have full intestinal tracts, which makes them lose commercial value. These characteristics, in combination with the simultaneous occurrence of the $R$. alatus breeding season and the period during which fishing restrictions are imposed due to spawning (the fish reproductive season), create a decline in the demand for earthworms and contribute to minimize the impact of extraction on population recruitment.

\subsection{Characteristics of the occurrence and distribution areas of Rhinodrilus alatus}

The distribution of $R$. alatus, originally reported in the scientific literature to be confined to two counties (Righi, 1971; Hofling, 1980; Righi and De Maria, 1998), has been extended to 17 municipalities in the São Francisco River Basin. Because most Brazilian earthworms are found in only a few locations (Brown and James 2007), the distribution of almost $80 \%$ of the species may be restricted. This information indicates a high degree of endemism and/or a lack of adequate collection representativeness. In the case of $R$. alatus, the previous data on its distribution (Righi, 1971; Hofling, 1980; Righi and De Maria, 1998) were insufficient to establish its degree of endemism. We report that the species has a wide distribution and occurs in different plant physiognomy of Cerrado, pastures and Eucalyptus spp. plantations. We have not studied no-tillage agroecosystems, once the extractors do not visit them.

Dystrophic and acid soils are characteristic of the areas of occurrence of $R$. alatus, but they do not explain its distribution because this type of soil occurs widely in other regions of Minas Gerais State (Curi et al., 2007). Other giant Glossoscolecidae also occur in savannas with acid soils, as exemplified by Martiodrilus carimaguensis (Jiménez et al., 1998).

Soil clay content seems to be important for the species' occurrence, as clay particles create the appropriate conditions needed for the construction of aestivation chambers and for their water retention. It is possible that clay content increases the tolerance of $R$. alatus to hydric stress. However, since our information is linked to extraction areas which had the soil characteristics presented in this study, we could not find any evidence of the species' occurrence in sandy soils.

Due to the characteristics of its annual life cycle, which closely follows the seasonal precipitation regimes, it is probable that $R$. alatus cannot survive in soils typical of sub-humid areas, such as those found in the north of its area of occurrence (Carvalho et al., 2007). It is also likely that the species is not able to live in udic soils that have fewer than three dry months per year (Curi et al., 2007), a characteristic of the areas to the south and east of its distribution range. Furthermore, the high altitude and stone outcrops characteristic of the Serra do Espinhaço mountain range to the east and the long São Francisco River to the west (see Figure 1) may represent physical barriers that prevented the spread of this species beyond its present home range.

The occurrence of $R$. alatus in pastures (Brachiaria spp.) and in Eucalyptus spp. plantations shows the resilience of this species to land use change. However, the process of soil preparation for the establishment and renovation of pastures, which includes plowing and liming, could reduce the earthworms' abundance both by increasing their mortality and by changing the physicochemical conditions of the soil. However, because this practice is not annual and varies according to the procedures of each landowner, its negative effects on the earthworm populations can be minimised. This variation in the practice of soil preparation could explain the abundance of $R$. alatus in pastures. However, the conversion of Cerrado areas into cultivated agricultural land could limit $R$. alatus populations because agriculture is usually associated with an increase in soil $\mathrm{pH}$ and with the use of pesticides. The presence of $R$. alatus populations in notillage agroecosystems has not yet been reported and further efforts are needed to assess whether they are able to survive under these condition.

\subsection{Abundance}

The data show a high abundance of giant earthworms in the study area. However, several external factors affect the measurement of the CPUE or R. alatus abundance. These factors include the extractors' ability and the history of extraction in different areas. The variability asso- 
ciated with these factors is reflected in the large standard deviations shown in our results. Because of the extraction illegality and of the non-monitored exploitation, no information about the extraction frequency exists. Therefore, it would be risky to make a comparative analysis of the species' abundance involving different localities, vegetation formations or differences between years.

We believe that the extraction method can promote the removal of more adults than juveniles because the last castings of juveniles, which indicate to the extractor the presence of the subterranean chamber, are smaller and more difficult to find. This feature is important to consider since it contributes to the maintenance of populations in the different ecosystems where it occurs.

A number of earthworms always remain in the soil during the extraction process because some areas are not disturbed by the extractors. Furthermore, the soil removed during digging hides the feces of other earthworms, making it difficult to capture all the individuals in the extraction area. Additionally, in the Cerrado and $\mathrm{Eu}$ calyptus spp. plantations, individuals aestivating near tree roots are seldom removed. These factors also contribute to maintain the $R$. alatus populations, even in frequently exploited areas.

It is not possible to establish quotas for extraction. To calculate the abundance in a particular area, all of the individuals need to be removed and the aestivation chambers, which are essential for their survival, are consequently destroyed. Those animals released into the capture areas, even immediately after the extraction, do not survive during the dry period.

The species is abundant and has a broad distribution. These characteristics facilitate the definition of areas where extraction could be allowed and other areas where it should be banned.

The species' life cycle, autotomy, abundance, distribution and resilience to land-use conversion are key elements in the planning of management strategies. Given this information, we consider the possibility of establishing use agreements and regulations.

A management plan for the species was elaborated in alliance with diverse stakeholders, integrating ecological, social and economic information. This plan comprises guidelines for the management of wild $R$. alatus population as well as feasibility of surveying and establishing captive breeding, protected areas, alternative sources of income for the local communities and management plan for other species of giant earthworm. These species are either commercially sold in Minas Gerais (Rhinodrilus motocu and a new species of Rhinodrilus) and, in some occasions, replace the trade of $R$. alatus.

Among the guidelines directly related to the management of $R$. alatus, the plan includes mandatory rules such as using the rotation method for extraction areas and ceasing the extraction of juveniles - avoiding narrow galleries - and in the rainy months, from November to March. Furthermore, the plan provides the continuous monitoring of the abundance and maturity of earthworms extracted and sold in the region and of the actions imple- mented. Such comprehensive monitoring aims to incorporate the concepts and practices of adaptive management, taking into account the complexity and unpredictability of this socioecological system (Berkes and Folke, 2000; Koontz and Bodine, 2008). Potential challenges to long-term sustainability include the interest of the governmental natural resource in supporting and maintaining faunal management in Brazil.

\section{Acknowledgments}

We are grateful for the support provided by the Instituto Estadual de Florestas de Minas Gerais (IEF-MG), Instituto Chico Mendes para a Conservação da Biodiversidade (ICMBio), Floresta Nacional de Paraopeba, Instituto Brasileiro de Meio Ambiente e Recursos Naturais Renováveis (Ibama), Pró-Reitorias de Pesquisas (PRPq) e de Extensão (ProEx) of Universidade Federal de Minas Gerais (UFMG) and Ministério Público do Estado de Minas Gerais (MPE). We are also grateful to the extractors and rural landowners of the study area for their aid during the fieldwork. Financial support was provided by IEF-MG, MPE, Conselho Nacional de Desenvolvimento Científico e Tenológico (CNPq), Fundação de Amparo à Pesquisa de Minas Gerais (FAPEMIG), Conservação Nacional do Brasil, PRPq and ProEx (UFMG). Finally, we thank Embrapa Soja for soil analysis.

\section{References}

ABE, AS. and BUCK, N., 1985. Oxygen uptake of active and aestivating earthworm Glossoscolex paulistus (Oligochaeta, Glossoscolecidae). Comparative Biochemistry and Physiology, vol. 81, no. 1, p. 63-66.

AYRES, I. and GUERRA, RT., 1981. Água como fator limitante na distribuição das minhocas (Annelida, Oligochaeta) na Amazônia Central. Acta Amazonica, vol. 11, p. 77-86.

BERKES, F. and FOLKE, C., 2000. Linking social and ecological systems. In BERKES, F. and FOLKE, C. (Eds.). Linking social and ecological systems. Management Practices and Social Mechanisms for Building Resilience. Cambridge: Cambridge University Press. p. 1-25.

BROWN, GG. and JAMES, SW., 2006. Earthworm diversity in Sao Paulo State, Brazil. European Journal of Soil Biology, vol. 42, no.1, p. 145-149.

BROWN, GG. and JAMES, SW., 2007. Ecologia, biodiversidade e biogeografia das minhocas no Brasil. In BROWN, GG. and FRAGOSO, C. (Eds.). Minhocas na América Latina: Biodiversidade e ecologia. Londrina: Embrapa Soja. p. 297-381.

BUCK, N. and ABE, AS., 1990. Atividade sazonal do minhocoçu Andiorrhinus samuelensis na região de Porto Velho, Rondônia (Oligochaeta, Glossoscolecidae). Ciência e Cultura (Sao Paulo), vol. 42, p. 835-838.

CARVALHO, LS., OLIVEIRA, MS., ALVES, MC., VIANELLO, RL., SEDIYAMA, GC., NETO, PC. and DANTAS, AAA., 2007. Clima. In SCOLFORO, JRL., CARVALHO, MT. and OLIVEIRA, AM. (Eds.). Zoneamento Ecológico e Econômico no Estado de Minas Gerais. Lavras: Universidade Federal de Lavras; Secretaria de Estado do Meio Ambiente de Minas Gerais. p. 89-102. 
CURI, N., MARQUES, JJ., SÁ, AF., MARQUES, M. and FERNANDES, EI., 2007. Solos, geologia, relevo e mineração. In SCOLFORO, JRL., CARVALHO, MT. and OLIVEIRA, AM. (Eds.). Zoneamento Ecológico e Econômico no Estado de Minas Gerais. Lavras: Universidade Federal de Lavras; Secretaria de Estado do Meio Ambiente de Minas Gerais. p. 73-88.

DÍAZ COSÍN, JD., RUIZ, MP., RAMAJO, M. and GUTIÉRREZ, M., 2006. Is the aestivation of the earthworm Hormogaster elisae a paradiapause? Invertebrate Biology, vol. 125 , no. 3, p. 250-255.

DRUMOND, MA., 2008. Manejo adaptativo do minhocuçu Rhinodrilus alatus. Belo Horizonte: Universidade Federal de Minas Gerais. 112 p. Tese de Doutorado em Ecologia, Conservação e Manejo da Vida Silvestre.

DRUMOND, MA., CAMPOS, SHC., GUIMARÃES, AQ. and NUNES, JT., 2008. Ecologia e uso do minhocuçu Rhinodrilus alatus. MG-Biota, vol. 1, no. 3, p. 5-23.

EDWARDS, CA. and BOHLEN, PJ., 1996. Biology and ecology of earthworms. London: Chapman \& Hall. $426 \mathrm{p}$.

EMBRAPA, 1997. Manual de métodos de análises de solo. Empresa Brasileira de Pesquisa Agropecuária. Rio de Janeiro: Centro Nacional de Pesquisa de Solos. 212 p.

-, 2006. Sistema Brasileiro de Classificação de Solos. Empresa Brasileira de Pesquisa Agropecuária. Rio de Janeiro: Centro Nacional de Pesquisa de Solos. 306 p.

FRAGOSO, C. and BROWN, G.G., 2007. Ecología y taxonomía de las lombrices de tierra en Latinoamérica: El primer Encuentro Latino-Americano de Ecología y Taxonomía de Oligoquetos (Elaetao1). In BROWN, GG. and FRAGOSO, C. (Eds.). Minhocas na América Latina: Biodiversidade e ecologia. Londrina: Embrapa Soja. p. 33-75.

GUERRA, RT., 1985. Ecologia dos oligochaeta da Amazônia. I. Estudo da migração horizontal e vertical de Chibui bari (Glossoscolecidae, Oligochaeta) através de observações de campo. Acta Amazonica, vol. 15, p. 141-146.

HOFLING, E., 1980. Sistema circulatório de Rhinodrilus alatus Righi, 1971 (Oligochaeta, Glossoscolecidae). Papéis Avulsos de Zoologia, vol. 34, no.3, p. 21-72.

JAMES, SW. and BROWN, GG., 2006. Earthworm ecology and diversity in Brazil. In MOREIRA, FMS., SIQUEIRA, JO. and BRUSSAARD, L. (Eds.). Soil biodiversity in Amazonian and other Brazilian ecosystems. Oxfordshire: CABI Publishing. p. 56-116.

JIMÉNEZ, JJ., MORENO, AG., LAVELLEB, P. and DECAËNSC, T., 1998. Population dynamics and adaptive strategies of Martiodrilus carimaguensis (Oligochaeta, Glossoscolecidae), a native species from the well-drained savannas of Colombia. Applied Soil Ecology, vol. 9, p. 153-160.

JIMÉNEZ, JJ., BROWN, GG., DECÄENS, T., FEIJOO, A. and LAVELLE, P., 2000. Differences in the timing of diapause and patterns of aestivation in tropical earthworms. Pedobiologia, vol. 44, p. 677-694.
JIMÉNEZ, JJ., DECAËNS, T., MARIANI, L. and LAVELLE, P., 2007. Biología y ecología de las lombrices de tierra de las sabanas neotropicales de Colombia. In BROWN, GG. and FRAGOSO, C. (Eds.). Minhocas na América Latina. Biodiversidade e ecologia. Londrina: Embrapa Soja. p. $155-175$.

KLINK, CA. and MACHADO, RB., 2005. A conservação do Cerrado Brasileiro. Megadiversidade, vol. 1, no. 1, p. $147-155$.

KOONTZ, TM. and BODINE, J., 2008. Implementing ecosystem management in public agencies: lessons from the U.S. Bureau of Land Management and Forest Service. Conservation Biology, vol. 22, no. 1, p. 60-69.

LEE, KE., 1985. Earthworms: Their ecology and relationships with soils and land use. Sydney: Academic Press. $411 \mathrm{p}$.

MARTIN, AW. and JOHANSEN, K., 1992. Circulation in the giant earthworm Glossoscolex giganteus: blood and extracellular fluid volumes. In WOOD, SC., WEBER, RE., HARGENS, AR. and MILLARD, RW. (Eds.). Physiological adaptations in vertebrates: respiration, circulation, and metabolism. New York: Marcel Dekker. p. 315325.

MITTERMEIER, RA., GIL, PR., HOFFMAN, M., PILGRIM, J., BROOKS, T., MITTERMEIER, CG., LAMOREUX, J. and FONSECA, GAB., 2004. Hotspots revisited. Mexico, DF: Cemex. 392 p.

RIGHI, G., 1971. Sobre a família Glossoscolecidae (Oligochaeta) no Brasil. Arquivos de Zoologia, vol. 20, no. 1, p. 1-96.

RIGHI, G. and DE MARIA, M., 1998. Rhinodrilus alatus Righi, 1971. In MACHADO, ABM., FONSECA, GAB., MACHADO, RB., AGUIAR, LM. and LINS, LV. (Eds.). Livro vermelho das espécies ameaçadas de extinção da fauna de Minas Gerais. Belo Horizonte: Fundação Biodiversitas. p. 579-581.

RODRIGUEZ, C., BORGES, S., MARTÍNEZ, MA., FRAGOSO, C., JAMES, SW. and GONZÁLEZ, G., 2007. Biodiversidad y ecología de las lombrices de tierra en las islas caribeñas. In BROWN, GG. and FRAGOSO, C. (Eds.). Minhocas na América Latina: Biodiversidade e ecologia. Londrina: Embrapa Soja. p. 79-99.

SCOLFORO JR., CARVALHO LMT. and OLIVEIRA AM., 2006. Mapeamento e inventário da flora nativa e dos reflorestamentos de Minas Gerais. Lavras: Editora UFLA. 579 p.

TAN, KH., 1993. Principles of Soil Chemistry. New York: Marcel Dekker. 521 p.

VALLE, JV., MORO, RP., GARVÍN, MH., TRIGO, D. and DÍAZ COSÍN, DJ., 1997. Annual dynamics of the earthworm Hormogaster elisae (Oligochaeta, Hormogastridae) in central Spaino. Soil Biology and Biochemistry, vol. 29, p. 309-312.

VALLE, JV., GARVÍN, MH., TRIGO, D., MARTÍNEZ, F., BELINCHÓN, C. and DÍAZ COSÍN, DJ., 1999. Vertical distribution of Hormogaster elisae (Oligochaeta, Hormogastridae) in soil at El Molar (central Spain). Pedobiologia, vol. 43, p. 859-865. 